\title{
Sulphate reduction, methanogenesis and phylogenetics of the sulphate reducing bacterial communities along an estuarine gradient
}

\author{
D. B. Nedwell ${ }^{1, *}$, T. M. Embley ${ }^{2}$, K. J. Purdy ${ }^{1,3}$ \\ ${ }^{1}$ Department of Biological Sciences, University of Essex, Colchester, Essex CO4 3SQ, UK \\ ${ }^{2}$ Molecular Biology Unit, Department of Zoology, Natural History Museum, London SW7 5BD, UK \\ ${ }^{3}$ Present address: School of Animal and Microbial Sciences, University of Reading, Whiteknights, PO Box 228, \\ Reading RG6 6AJ, UK
}

\begin{abstract}
Four sites were investigated along the salinity gradient in the estuary of the River Colne, UK. Sulphate reduction rates at all sites decreased with depth in the sediment, but the annual rate of sulphate reduction over the 0 to $20 \mathrm{~cm}$ profile did not decrease significantly, even at a low salinity site up the estuary where sulphate concentrations were much lower than at the estuary mouth. Methane was formed at all of the sites, at rates 2 orders of magnitude lower than sulphate reduction, and was greatest at a site on the marsh top site where organic matter was high. Methane emissions to the atmosphere were substantially lower than sedimentary methanogenesis, suggesting methane oxidation occurred in the sediments before emission, with the proportion oxidized before emission increasing down the estuary. Nucleic acids were extracted from the sediments at each site, slot-blotted onto nylon membranes, and 16S rRNA quantified with radiolabelled oligonucleotide probes against different groups of sulphate reducing bacteria (SRB). Autoradiographs were quantified by laser densitometry compared to known standards of RNA, and expressed as a percentage of the signal from a total bacterial probe. The 4 SRB genera analysed (Desulfovibrio, Desulfobacter, Desulfobulbus and Desulfobacterium) were all detected at all 4 sites. Desulfovibrio was the largest group of SRB at the 3 lower estuary sites, while Desulfobacter, which appeared to be the major acetate utiliser present along the estuary, and Desulfobulbus were detected at lower levels. Signal from the physiologically diverse Desulfobacterium occurred at significantly higher levels in the upper estuary at the Hythe, and it was possible that this was associated with its use of electron acceptors other than sulphate, such as nitrate.
\end{abstract}

KEY WORDS: Estuarine sediments - Sulphate reduction · Methane formation · Methane oxidation · Sulphate reducing bacteria $\cdot$ Methanogenic archaea $\cdot 16 \mathrm{~S}$ rRNA

\section{INTRODUCTION}

Sulphate reduction and methanogenesis are important terminal oxidation processes in the anaerobic mineralisation of organic matter and can be seen as ecological equivalents, mineralising organic matter to $\mathrm{CO}_{2}$, or $\mathrm{CO}_{2}$ and $\mathrm{CH}_{4}$ in, respectively, high and low sulphate environments (Winfrey \& Zeikus 1977). Sulphate reduction is thought to outcompete methano- genesis when sulphate is freely available (e.g. in marine sediments) as cultured strains of sulphate reducing bacteria (SRB) have higher specific affinities than methanogenic archaea (MA) for the main substrates (acetate and $\mathrm{H}_{2}$ ) used by both groups (Balba \& Nedwell 1982, Kristjansson et al. 1982, Lovley et al. 1982). However, even in marine sediments methanogenesis still occurs, primarily via $\mathrm{C}_{1}$-compounds, such as methylamines, that SRB cannot use (Winfrey \& 
Ward 1983). In freshwater environments, where available sulphate is usually limited, sulphate reduction still occurs but methanogenesis usually dominates (Lovley \& Klug 1983, Takii \& Fukui 1991). Sulphate reduction accounts for up to $50 \%$ of organic matter degradation in coastal marine sediments and similar proportions have been shown for methanogenesis in freshwater systems (Jørgensen 1982, Lovley et al. 1982). However, little work has been done that links process measurements and the identities of the key players in these processes in situ.

Little is known about the identities of the important SRB in situ. Molecular methods provide a means of estimating, through in situ probing, the relative abundance of different SRB genotypes. Oligonucleotide probes specific to the 16S rRNA of different SRB genera (Devereux et al. 1992) have already been used to investigate the identities of SRB in a number of anaerobic sediments. Thus, it has been suggested that the genera Desulfovibrio and Desulfobulbus may be important in both freshwater and marine sediments (Devereux et al. 1996, Trimmer et al. 1997, Li et al. 1999, Minz et al. 1999, Sahm et al. 1999b). In contrast, our previous work using probes and fatty-acidamended sediment slurries has suggested that Desulfobacter are active in marine sediments, Desulfobulbus are active in freshwater and marine sediments and that Desulfovibrio appeared to play only a minor role in sediments from the River Tama in Japan (Purdy et al. 1997). Sediment slurry experiments from the Colne estuary, Essex, UK, have supported the results of similar slurry experiments from the River Tama, indicating that Desulfobacter are the primary acetate-utilising SRB in sediments where sulphate is freely available (Purdy et al. 2003a). Studies on sediments from both the Arctic and Antarctic suggest that there are differences between the SRB communities found in permanently low-temperature sediments compared to temperate sediments (Sahm et al. 1999a, Purdy et al. 2003b). Here we extend this previous work on temperate and polar sediments to investigate the in situ rates of sulphate reduction and methanogenesis as well as the relative activity of different SRB genotypes along the River Colne estuary.

\section{MATERIALS AND METHODS}

Study sites and sampling. Four sites were sampled in the estuary of the River Colne, Essex, UK. Two were on the Colne Point salt marsh at the mouth of the estuary; one in the soft open mud near the tip of a salt marsh creek (Open Mud); and one on the flat vegetated surface of the marsh (the Marsh Top) in an area adjacent to the creek site. A further 2 saltmarsh sites were at
Alresford Creek (Alresford), in the middle of the estuary, and the Hythe at Colchester near the top of the estuary (see Ogilvie et al. 1997 for description of sites). The Colne Point saltmarsh sites are subjected to twice daily inundation by coastal seawater, and have fully marine intertidal conditions (salinity 32 to $34 \%$ ). Midestuary Alresford Creek has reduced salinity in the range of 20 to $30 \%$, while salinity at the Hythe is typically in the range of 0 to $10 \%$.

Triplicate sediment cores of approximately $30 \mathrm{~cm}$ long were taken with a perspex core tube $(8 \mathrm{~cm}$ internal diameter by $50 \mathrm{~cm}$ length) at approximately monthly intervals from all 4 sites; from September 1994 to August 1995 at Colne Point, and from May 1995 to May 1996 at Alresford and the Hythe. Cores were maintained at the measured in situ temperature and returned to the laboratory within $1 \mathrm{~h}$. Each large core was then placed in an anaerobic glove bag under $\mathrm{N}_{2}: \mathrm{CO}_{2}(80: 20 \% \mathrm{v}: \mathrm{v})$ and subsampled over the $0-5$, $5-10,10-15$ and $15-20 \mathrm{~cm}$ depth horizons with cut-off $5 \mathrm{ml}$ sterile plastic hypodermic syringes. Replicate small cores of sediment from each site and horizon were used to measure sediment bulk density and porosity .

Analysis of methane and sulphate. Concentrations of sulphate in sediments were measured by centrifuging replicate small cores of sediment $(1000 \times g$ for $20 \mathrm{~min}$ ) to recover porewater samples. These samples were acidified with $50 \mu \mathrm{l}$ hydrochloric acid ( $50 \% \mathrm{v}: \mathrm{v})$ to remove sulphide and then analysed for sulphate by ion exchange chromatography (series 2000i, Dionex).

Methane was analysed by gas-liquid chromatography with a flame ionization detector using oxygenfree $\mathrm{N}_{2}$ as the carrier gas (Nedwell \& Banat 1981).

Emission of methane from sediment. Triplicate perspex boxes $\left(0.25 \mathrm{~m}^{2}\right.$ by $10 \mathrm{~cm}$ depth), with a rubber septum in the upper surface to permit withdrawal of head space gas samples, were placed randomly on the surface of the sediment at each site. The wet sediment gave a good gas seal for the boxes. Head space gas samples were taken at $0.5 \mathrm{~h}$ intervals for $4 \mathrm{~h}$. After return to the laboratory, methane in the head space was measured and the rate of methane emission in each box was determined by fitting a linear regression to the head space methane concentrations, and calculating the emission rate allowing for the head space volume and the area of sediment covered by the box. The mean rate of methane emission and standard error of the mean (SEM) were then calculated from the triplicates.

Rates of methane emissions were integrated with respect to time between sampling dates by linear interpolation. As there was not a complete year's sampling at Alresford, the integrated total over the sampling period was multiplied proportionately up to an annual value. 
Methane formation in the sediment. Methanogenesis was determined by head space accumulation of methane from triplicate sub-cores from $5 \mathrm{~cm}$ depth slices extruded, in an OFN (oxygen-free nitrogen)-flushed gas bag, into previously gassed $50 \mathrm{ml}$ serum bottles, crimp sealed with butyl septa and incubated at in situ temperatures for up to $4 \mathrm{~d}$. Samples (50 $\mu \mathrm{l}$ ) of the head space gas were taken from each bottle via the septum each day and the methane concentration in the head space measured as above. Methane formation rates per $\mathrm{ml}$ of sediment in each bottle were determined by fitting a linear regression to each plot of head space methane concentration against time, and allowing for the head space volume and the known volume of sediment. Rates of formation of methane were tested for significant $(p<0.05)$ difference from zero with a modified Student's $t$-test. The mean rates $( \pm \mathrm{SEM})$ were calculated for each depth horizon. Methane formation was integrated with respect to depth over the 0 to $20 \mathrm{~cm}$ horizon, and with respect to time by linear interpolation.

In situ rates of sulphate reduction. To measure sulphate reduction rates, triplicate small cores of sediment from each depth horizon were injected along their length with $50 \mu \mathrm{l}$ of an anaerobic solution of sodium ${ }^{35} \mathrm{~S}$-sulphate solution (containing $1 \mu \mathrm{Ci}$ [37 KBq] of carrier-free ${ }^{35} \mathrm{~S}$-sulphate [specific activity $\left.3.7 \mathrm{GBq} \mathrm{mmol}{ }^{-1}\right]$ ) and incubated for $24 \mathrm{~h}$ at the measured in situ temperature. At the end of this period, each small core was extruded into $5 \mathrm{ml}$ of zinc acetate solution $(20 \mathrm{mM})$ to fix sulphides. The sediment cores were subsequently digested with tin and hydrochloric acid and radioactivity in both acid-volatile sulphides and pyrite was determined (Nedwell \& Takii 1988). Subsamples of the residual ${ }^{35} \mathrm{~S}$-sulphate left in solution after the digestion were also taken for each sediment core so that the radioactivity added to each core could be accurately determined. The depth-integrated rate of sulphate reduction over the 0 to $20 \mathrm{~cm}$ horizon was also calculated for each site and occasion, and integrated with respect to time between sampling dates by linear interpolation.

Extraction of nucleic acids from sediment samples and pure culture controls. Sediment samples were taken from the 2 Colne Point sites over 7 mo from March until September, at Alresford from May until September and at the Hythe from June until August and washed with $120 \mathrm{mM}$ sodium phosphate, $\mathrm{pH}$ 8.0, before extracting DNA and RNA separately (Purdy et al. 1996). SRB (see Table 1) were grown as described by Widdel \& Bak (1992). A non-SRB control (Bacillus subtilis NCMB 3610) was grown in nutrient broth. Total RNA was extracted from pure cultures as described previously (Purdy et al. 1997).

Immobilisation of extracted nucleic acids onto nylon membranes and hybridisation conditions: Nucleic acids (either 50 or $500 \mathrm{ng}$ total RNA per slot) were slot-blotted onto nylon membrane (Hybond-N, Dupont) after denaturation using $2 \% \mathrm{w}: \mathrm{v}$ glutaraldehyde (Purdy et al. 1997) along with known amounts of rRNA from pure culture controls. Oligonucleotide probes (Table 1) were synthesised commercially and end-labeled with $\gamma$ - ${ }^{32}$ P-ATP (Amersham Biosciences) (Sambrook et al. 1989). Hybridisations were performed and membranes processed as described previously (Purdy et al. 1997).

Scanning densitometry of autoradiographs and determination of signal levels: Autoradiographs were quantified using laser densitometry (300A Computing Densitometer, Molecular Dynamics). Densitometrically measured signals were converted to an amount of rRNA for each sample by comparison to pure culture control standard curves (Purdy 1997, Purdy et al. 1997). The standardised results are expressed as a percentage of the general bacterial probe (p338) signal. This is a composite measure of both the population size (number of cells) and the activity of individual cells as expressed by intracellular 16S rRNA (Rosset et al. 1966). Means and standard deviations were deter- 
mined after arcsine transformation of the percentage data and then back transformed to give the quoted results (Zar 1996). Differences between samples were tested for statistical significance by a 1-way ANOVA with a post-hoc Tukey test for uneven $\mathrm{n}$ (Zar 1996). Data are presented as the mean for all sampling times from each site.

\section{RESULTS}

The rates of methane efflux from the sediments along the Colne River estuary are shown in Fig. 1. There was a strong seasonal signal at all sites, with peaks of methane emission during July and August 1994 at the 2 sites on Colne Point (Fig. 1A,B), decreas-

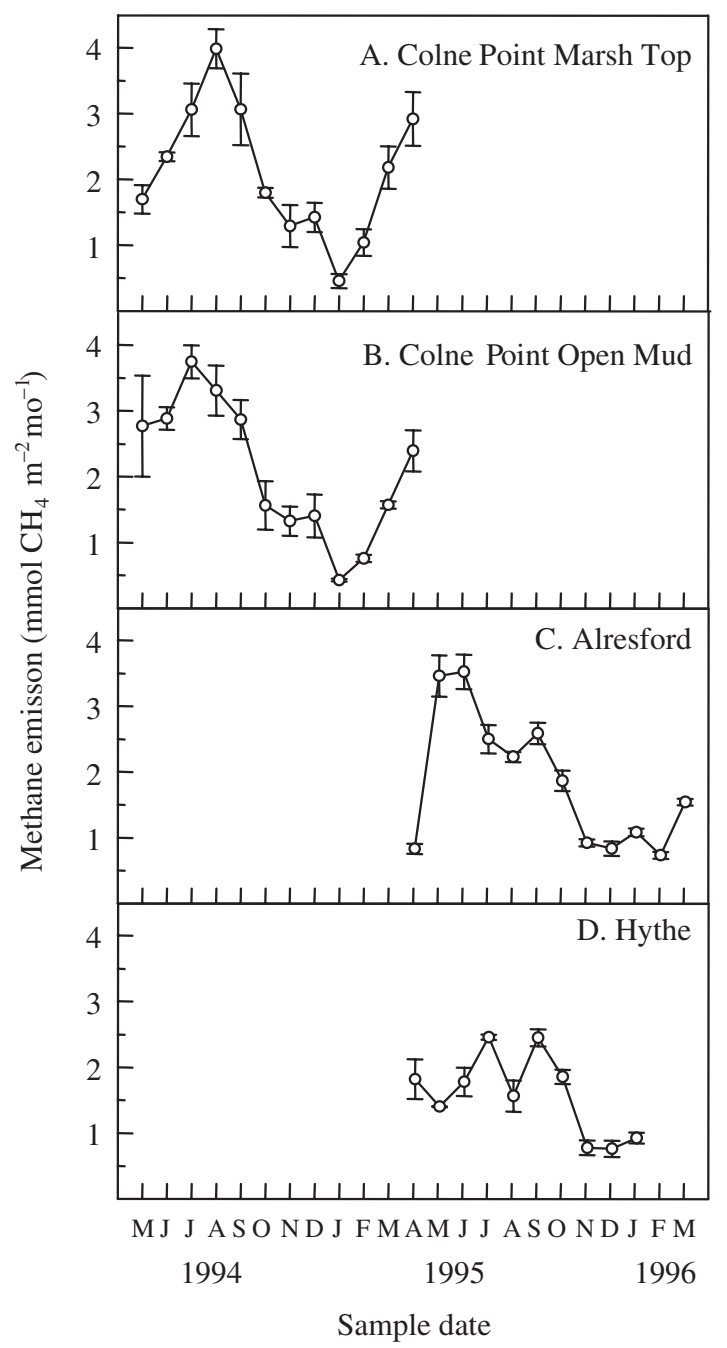

Fig. 1. Sediment surface methane emission rates from 4 sites along the River Colne estuary in Essex, UK (1994 to 1996). Data represent means of triplicate samples, error bars = \pm 1 SEM ing strongly during winter. There were broader peaks during the summer in May and June in the upper estuary at Alresford and the Hythe.

Methane formation within the sediments displayed similar seasonal changes, with peaks during the summer at all sites (Fig. 2A). The mean annual rates of methane formation decreased with increasing depth at all sites (Fig. 2B), reflecting the decrease in available organic matter with increased depth in such intertidal sediments (Nedwell \& Gray 1987).

Sulphate reduction rates (Fig. 3) similarly showed strong summer peaks, with rates of sulphate reduction decreasing with increased depth in the sediment. It was apparent from the data that there was neither spatial nor temporal separation between sulphate reduction and methanogenesis.

Table 2 shows the total annual amounts of methane emissions, methane formation and sulphate reduction (in carbon equivalents) at each site over the 0 to $20 \mathrm{~cm}$ horizon. Methane efflux to the atmosphere was relatively constant at all 4 sites, but was always less than the methane formation measured at the same site. At the Colne Point sites, $>75 \%$ of the methane formed was apparently not emitted from the surface, while $57 \%$ of the methane formed at the Hythe, and $20 \%$ at Alresford were lost before emission.

Sulphate reduction accounted for between 70- and 560 -fold more carbon flow than did methane formation at all sites. There was no apparent trend between sites, with annual amounts similar along the estuary.

Signal from the 4 genus-targeted probes, p129 (Desulfobacter), p221 (Desulfobacterium), p660 (Desulfobulbus) and p687 (Desulfovibrio), as well as the general Desulfobacteriaceae probe (p804) were detected at all 4 sites. Signal from p814 (Desulfococcaceae) was not detected at these sites. The total SRB community, as determined by the combined signal for the 4 genustargeted probes, was larger at the Open Mud and Hythe sites $(20.8 \%, \mathrm{SEM}=1.6, \mathrm{n}=7$, and $24.2 \%, \mathrm{SEM}=5.5, \mathrm{n}=$ 3 , respectively) compared to that detected at the Marsh Top or Alresford sites $(8.8 \%, \mathrm{SEM}=1.2, \mathrm{n}=7$, and $8.5 \%$, $\mathrm{SEM}=0.7, \mathrm{n}=5$, respectively), but the only statistically significant difference was between the Open Mud site and the Marsh Top site $\left(F_{1,3}, \mathrm{p}<0.05\right)$.

There were few significant differences in the proportions of the detected SRB genera across the 4 sites. Signal from the Desulfobacter and Desulfovibrio probes were not significantly different across all 4 sites. Signal from the Desulfobacterium probe (p221) was not significantly different between the 3 sites nearest the mouth of the estuary but was significantly higher at the Hythe $\left(F_{1,3}, \mathrm{p}<0.001\right)$. Signal from the Desulfobulbus-targeted probe (p660) was significantly higher in the Open Mud samples than in the Marsh Top samples $\left(F_{1,3}, \mathrm{p}<0.05\right)$. 


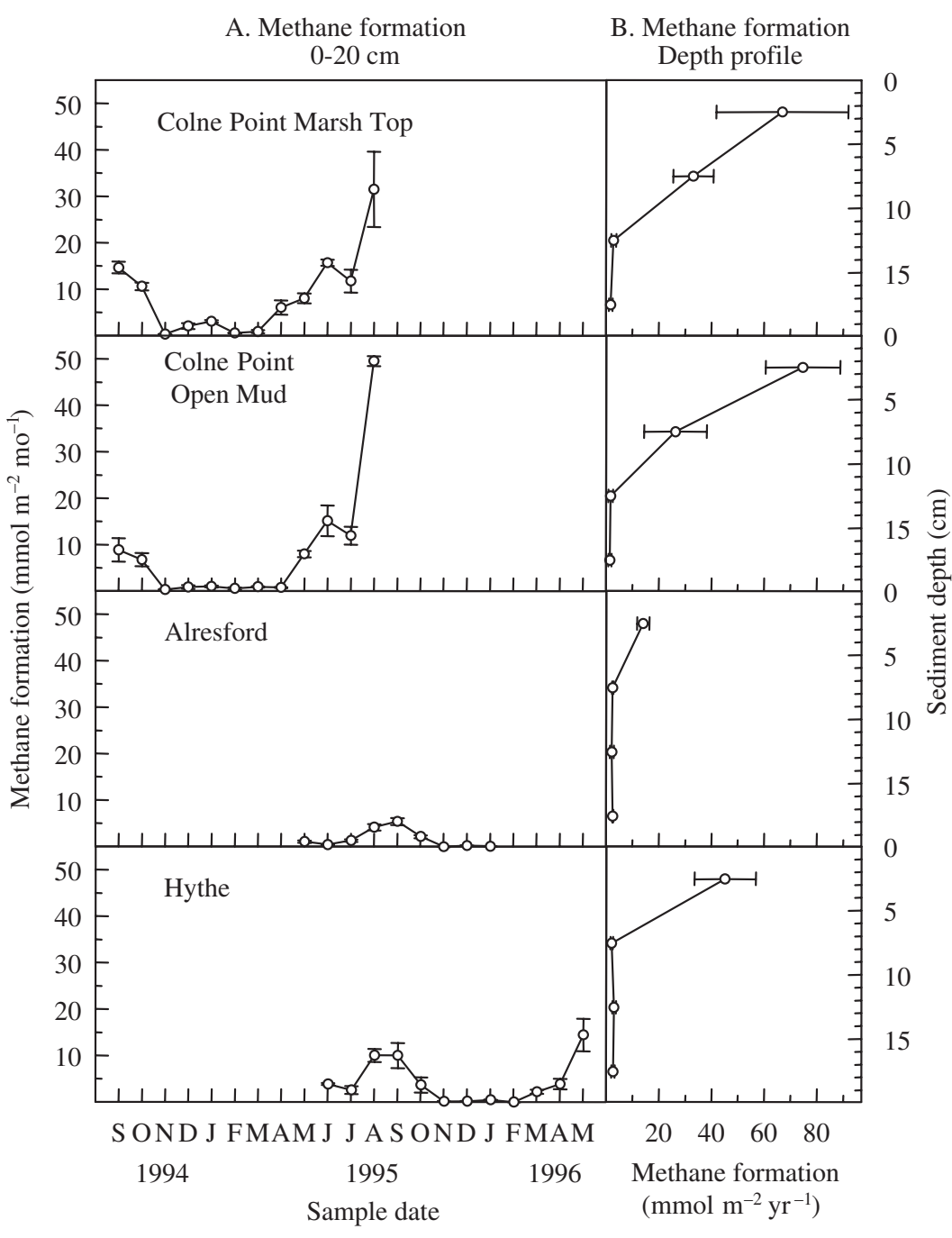

Fig. 2. Sediment methane production rates from 4 sites along the River Colne estuary in Essex, UK (1994 to 1996). (A) Monthly rates (mmol m${ }^{-2} \mathrm{mo}^{-1}$ ) integrated over 0 to $20 \mathrm{~cm}$ for each site. (B) Mean annual methane formation rates $\left(\mathrm{mmol} \mathrm{m}^{-2} \mathrm{yr}^{-1}\right)$ at $5 \mathrm{~cm}$ depth horizons over the top $20 \mathrm{~cm}$. Error bars $= \pm 1 \mathrm{SEM}$

(A, $\mathrm{n}=3 ; \mathrm{B}, \mathrm{n}=36$ [Open Mud, Marsh Top and Hythe], $\mathrm{n}=27$ [Alresford])

Nedwell 1978), and it might be predicted that in the low salinity upper estuary bottom sediments, sulphate reduction would be inhibited and methane formation elevated. However, our measurements showed no reduction in sulphate reduction rates even at the Hythe, despite the low salinity at this site, and the generally much lower benthic sulphate concentrations than in the fully marine sediments. This suggested that, although depleted, there was sufficient sulphate present in the porewaters of these upper estuary sediments to maintain high sulphate reduction rates. Porewater sulphate concentrations were always greater than the concentration that starts to limit sulphate reduction $(<1 \mathrm{mM}$; Boudreau \& Westrich 1984). The annual totals of sulphate reduction measured here at Colne Point (18.3 and $7.4 \mathrm{~mol} \mathrm{C} \mathrm{m}{ }^{-2} \mathrm{yr}^{-1}$ in Marsh Top and Creek Open Mud, respectively) can be compared with the values reported by Senior et al. (1982), averaging 4.6 and $3.2 \mathrm{~mol} \mathrm{C} \mathrm{m}^{-2} \mathrm{yr}^{-1}$ for creek and pan, respectively, which suggests broad interannual stability in the amounts of sulphate reduction proceeding in these sediments.

Correspondingly, the annual totals of methane emission to the atmosphere (Table 2) at the 4 sites showed that there was no trend of increase in methane emissions in the upper estuary at the Hythe, where benthic methane formation rates were actually less than at Colne Point. It has been suggested that denitrification can inhibit methanogenesis (Scholten et al. 2002), which

\section{DISCUSSION}

Our original intention in this work had been to select stations which would give a complete range of sediments from fully marine high sulphate to essentially low sulphate freshwater sediments. The site at the Hythe rarely exhibited salinity elevated above freshwater but it became clear subsequently that there was, nevertheless, significant sulphate and benthic sulphate reduction present, presumably from periodic penetration of tidal water providing sufficient sulphate.

The competition between SRB and methanogenic archaea for the limited substrates available in sediments is well known (Winfrey \& Zeikus 1977, Abram \& may explain the decreased methane production in the nitrate-rich upper parts of the estuary. The emission of methane from the open mud creek site at Colne Point (25 mmol $\mathrm{C} \mathrm{m}^{-2} \mathrm{yr}^{-1}$ ) again can be compared with an annual rate of emission in 1980 of $6.6 \mathrm{mmol} \mathrm{C} \mathrm{m} \mathrm{m}^{-2} \mathrm{yr}^{-1}$ reported by Senior et al. (1982). However, the rates of methane emissions (e.g. maximum about $130 \mu \mathrm{mol} \mathrm{m}{ }^{-2}$ $\mathrm{d}^{-1}$ at Colne Point in summer) were very small at all sites compared to truly freshwater sites (e.g. $2400 \mu \mathrm{mol}$ $\mathrm{m}^{-2} \mathrm{~d}^{-1}$ from a peat bog in summer; Nedwell \& Watson 1995), and again suggested that although depleted, there was sufficient porewater sulphate to avoid sulphate limitation of sulphate reduction and correspondingly to competitively inhibit the activity of methanogenic archaea. 


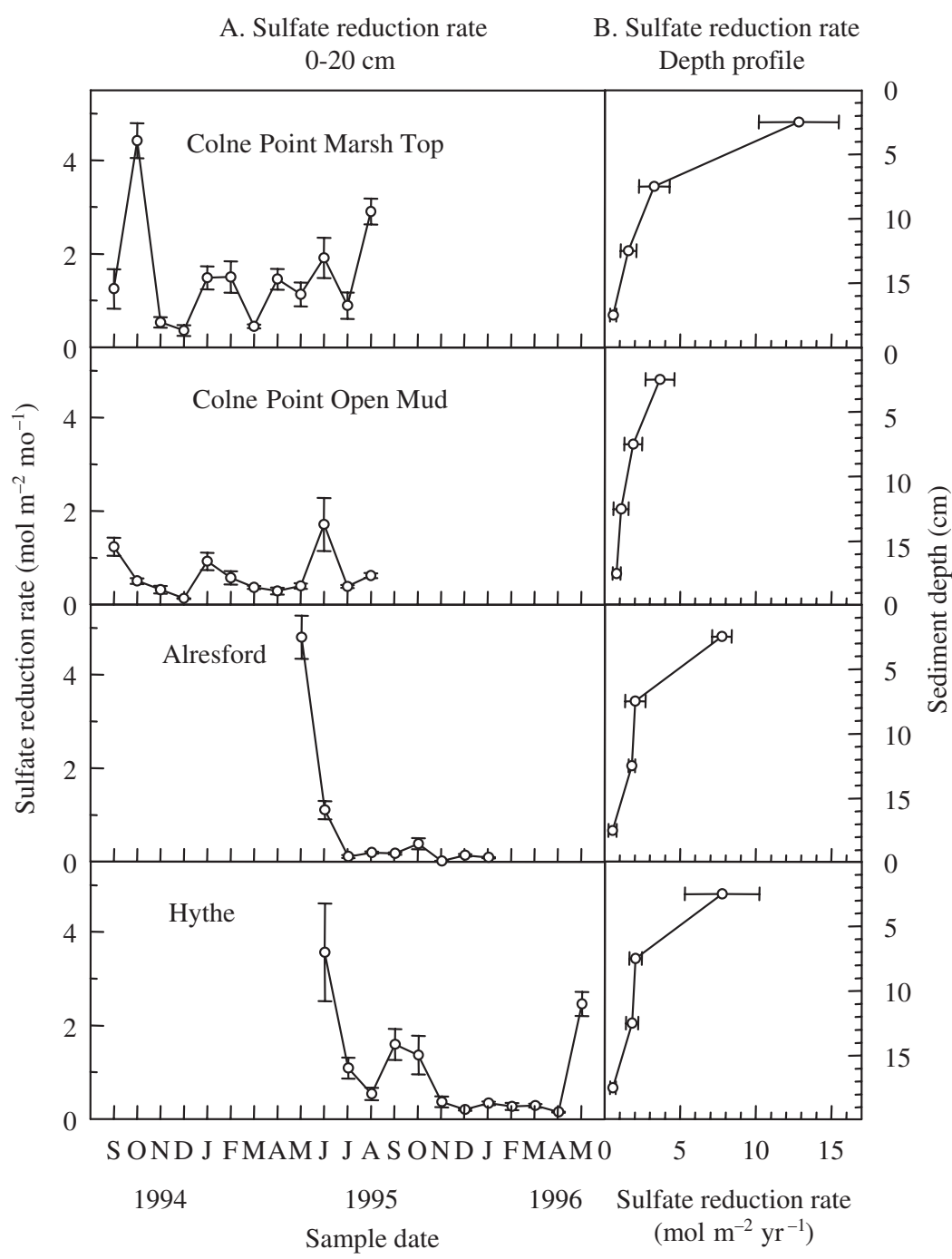

Fig. 3. Sediment sulphate reduction rates from 4 sites along the River Colne estuary in Essex, UK (1994 to 1996). (A) Monthly rates $\left(\mathrm{mol} \mathrm{m}^{-2} \mathrm{mo}^{-1}\right.$ ) integrated over 0 to $20 \mathrm{~cm}$ for each site. (B) Mean annual methane formation rates $\left(\mathrm{mol} \mathrm{m}^{-2}\right.$ $\left.\mathrm{yr}^{-1}\right)$ at $5 \mathrm{~cm}$ depth horizons over the top $20 \mathrm{~cm}$. Error bars $= \pm 1 \operatorname{SEM}(\mathrm{A}, \mathrm{n}=3$; $\mathrm{B}, \mathrm{n}=36$ [Open Mud, Marsh Top and Hythe], $\mathrm{n}=27$ [Alresford])

represented only a proportion of the methane formed within the 0 to $20 \mathrm{~cm}$ horizon of sediment (within which most benthic activity is located), and the proportion released to the atmosphere increased up the estuary, from $25 \%$ at Colne Point to $80 \%$ at Alresford. It has been shown previously that higher plants pump oxygen out through their roots to maintain an oxic rhizosphere (Schutz et al. 1991, Watson et al. 1997), which contributes greatly to the subsurface oxidation of methane. Therefore, it is likely that the presence of higher plant cover at Colne Point contributed to the high benthic methane oxidation at this site.

The relative sizes of the SRB community detected at the Open Mud and Hythe sites (Fig. 4) were larger than those detected at Marsh Top and Alresford, but the only statistically significant difference was between the 2 Colne Point sites (Open Mud > Marsh Top; p < 0.05). The Marsh Top site had annual rates of sulphate reduction more that twice as high as those in the Open Mud site and it may be that the SRB community at the Marsh Top site represented a smaller proportion of a larger, more active total bacterial community. Alternatively, the Marsh Top site is intertidally exposed to the air for longer than the Open Mud site would be and therefore a smaller proportion of the available organic carbon may be mineralised by sulphate reduction. The relative activity of the SRB communities at these 4 sites compares well with that detected in a Japanese estuary, where 2 predominately marine sites had a total SRB

The higher rates of both sulphate reduction and methanogenesis in the saltmarsh sites at Colne Point are probably associated with a greater availability of organic substrates than at the sites higher up the estuary. Both above- and below-ground primary production is high in saltmarshes (Hussey \& Long 1982, Long \& Mason 1983), and roots of higher plants may also excrete soluble organic matter into the rhizosphere to dispose of excess reducing power (Skyring et al. 1979, Nedwell et al. 1994). The Marsh Top site is heavily vegetated and the sediment has more total organic carbon (as a \% of dry weight) than the Open Mud site (Munson et al. 1997). The amounts of methane released from the sediment surface at all sites, though, community of 10 to $11.4 \%$ (SEM $=0.8$ to $1.4, \mathrm{n}=3$ or 4 ; Purdy et al. 2001). However, it should be noted that the probes were designed from the sequences of SRB strains in culture and, as such, may not represent the extent of genetic diversity within each genus. Conversely, they may cross-react with strains from outside their target genus that are, as yet, uncharacterised.

About $60 \%$ of the sulphate reduction in these Colne Point sediments is driven by acetate (Ogilvie et al. 1997). The relative activity of the acetate-utilising Desulfobacter was similar across all 4 sites (2.0 to $5.0 \%$ ). We have previously linked Desulfobacter to acetate-utilisation in marine-dominated estuarine sediments (Purdy et al. 1997, 2003a) and have shown 
Table 2. Annual totals (1994 to 1995) of methane emission, methane production and sulphate reduction, on a carbon basis $\left(\mathrm{mmol} \mathrm{C} \mathrm{m}{ }^{-2}\right.$ $\mathrm{yr}^{-1}$; mean $\pm \mathrm{SE}, \mathrm{n}=3$ ). Rate of methane formation $\times 1$, of sulphate reduction $\times 2$

\begin{tabular}{|lcccc|}
\hline Site & $\begin{array}{c}\mathrm{CH}_{4} \\
\text { emission }\end{array}$ & $\begin{array}{c}\mathrm{CH}_{4} \\
\text { production }\end{array}$ & $\begin{array}{c}\text { Sulphate } \\
\text { reduction }\end{array}$ \\
\hline Colne Point & Marsh Top & $25.3 \pm 1.0$ & $105 \pm 8.8$ & $18300 \pm 990$ \\
& Open Mud & $25.0 \pm 1.2$ & $105 \pm 5.0$ & $7440 \pm 660$ \\
Alresford & & $17.7 \pm 0.5$ & $22.1 \pm 1.1$ & $12000 \pm 1240$ \\
The Hythe & $22.3 \pm 0.6$ & $51.7 \pm 5.1$ & $9460 \pm 520$ \\
\hline
\end{tabular}

that this group is an important component of the SRB community in a Japanese estuary (Purdy et al. 2001). Our data indicate substantial activity from a Desulfobacter community in the Colne estuary sediments, suggesting that acetate degradation at these sites occurs via Desulfobacter. Other reports, using stable isotope-labeling of lipids, have linked acetate utilisation in marine sediments to Desulfotomaculum or Desulfofrigus (Boschker et al. 1998, 2001). Further work is necessary to explore the basis for this apparent incongruence and to determine if it is biological or methodological. Studies on Arctic and Antarctic coastal marine sediment indicate that Desulfobacter may not represent a detectable component of the SRB community in these permanently low-temperature sediments (Sahm et al. 1999b, Purdy et al. 2003b). These data suggest that Desulfobacter may not be a globally ubiquitous acetate-utilising SRB.

The detection of Desulfobulbus at all sites supports previous results which suggest that Desulfobulbus represent a small but significant component of all sedimentary bacterial communities whether marine or freshwater (Krylova et al. 1997, Trimmer et al. 1997, Li et al. 1999, Sahm et al. 1999a, Purdy et al. 2001, 2002). We have hypothesised that Desulfobulbus may be ubiquitous components of sedimentary communities (Purdy et al. 2001) and the present data support this hypothesis.

The detection of significant signal from Desulfovibrio (p687) at all 4 sites indicated that the SRB community of the Colne estuary is different from that in a Japanese estuary (Purdy et al. 2001). In the Japanese estuary, Desulfovibrio was only intermittently detected and Desulfobacter was the dominant SRB found at marine dominated sites. Desulfovibrio has been linked to peaks in sulphate reduction activity in a high sulphate freshwater region of the Great Ouse estuary, Norfolk, UK (Trimmer et al. 1997), and to mercury methylation in a sandy sediment in the US (Devereux et al. 1996). It is still unclear exactly what substrates are utilised by Desulfovibrio in situ. The primary substrates used to isolate and grow Desulfovibrio isolates are lactate and hydrogen (Widdel \& Bak 1992). However, there is little evidence to support a major role for lactate in sulphate reduction in situ (Laanbroek \& Pfennig 1981, Parkes et al. 1989, Purdy et al. 1997), which would suggest that Desulfovibrio may primarily utilise hydrogen in these sediments. In polar sediments, organisms related to the psychrophilic Desulfotalea appear to fulfill the role of Desulfovibrio (Sahm et al. 1999b, Purdy et al. 2003b), suggesting a level of biogeographical complexity in the distribution of this organism.

The significantly larger signal from the Desulfobacterium-targeted probe p221 at the Hythe $(12.6 \%$, $\mathrm{SE}=3.3 \%, \mathrm{n}=3$ ) is the largest reported proportion of a bacterial community detected by this probe in any sediment (Devereux et al. 1996, Trimmer et al. 1997, Li et al. 1999, Purdy et al. 2001). This suggests that the dynamics of sulphate reduction at this lower-sulphate site are distinct from those at the other 3 sites. However, Desulfobacterium spp. are physiologically very diverse, with many strains capable of utilising alternative electron acceptors such as nitrate and nitrite (Szewzyk \& Pfennig 1987, Widdel \& Bak 1992) and this

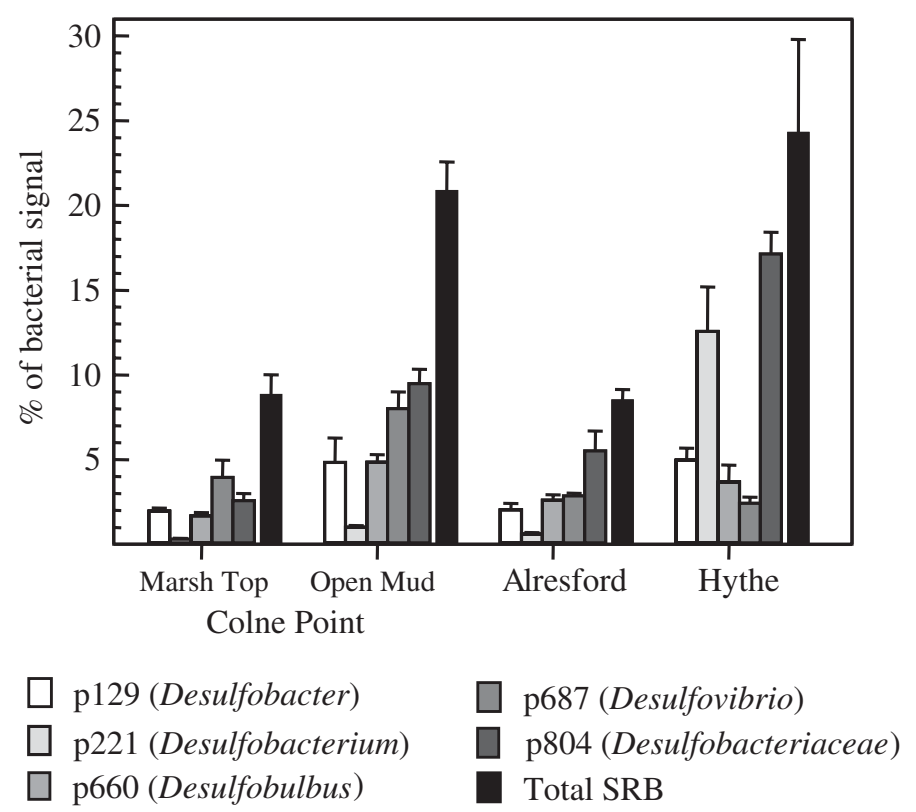

Fig. 4. Hybridisation of sulphate reducing bacteria (SRB) targeted oligonucleotide probes to rRNA extracted from sediment from 4 sites along the River Colne estuary, Essex, UK. Data expressed relative to signal from a general bacterial probe (p338). Signal level means were determined after arcsine transformation of the data. Data were statistically analysed using a 1-way ANOVA with a post-hoc Tukey test for uneven $n$ (Zar 1996). Results are means of 3 (the Hythe), 5 (Alresford) or 7 (Open Mud and Marsh Top) extractions, error bars $=+1$ SEM 
genus has been detected in low-sulphate environments (Li et al. 1999, Purdy et al. 2001). Therefore, it is possible that this peak of Desulfobacterium activity may not be associated with sulphate reduction but with an alternative process such as denitrification. The Hythe site is in a region of the estuary where sewage effluent and terrestrial inputs lead to elevated levels of nitrate and nitrite, making denitrification an important terminal oxidation process.

The 4 sites studied had very similar SRB communities with the exception of the Desulfobacterium community at the Hythe. However, it is possible that this group is not actively reducing sulphate at this site, which could explain the unique predominance of this group at this site. The detected SRB represent a very different distribution of organisms to those found in a Japanese estuary, where Desulfovibrio was only a small, insignificant part of the community while in the Colne estuary this genus is a ubiquitous member of the SRB community. Desulfobulbus were a small but significant component of the bacterial community in these sediments, giving further support for a ubiquitous role for this genus in sedimentary degradation of organic matter (Purdy et al. 2001). As in the Tama Estuary in Japan, Desulfobacter were detected in these sediments (Purdy et al. 1997, 2001), suggesting that this genus may be the primary acetoclastic sulphate reducer in both Colne and Tama sediments.

Acknowledgements. This work was funded by the Natural Environment Research Council, UK (Grant GR3/8958 to D.B.N. and T.M.E.). K.J.P. was funded by the Daiwa AngloJapanese Foundation, London.

\section{LITERATURE CITED}

Abram JW, Nedwell DB (1978) Hydrogen as a substrate for methanogenesis and sulphate reduction in anaerobic saltmarsh sediments. Arch Microbiol 117:93-97

Amann RI, Stromley J, Devereux R, Key R, Stahl DA (1992) Molecular and microscopic identifications of sulfatereducing bacteria in multispecies biofilms. Appl Environ Microbiol 58:614-623

Balba MT, Nedwell DB (1982) Microbial metabolism of acetate, propionate and butyrate in anoxic sediments from the Colne Point saltmarsh, Essex, UK. J Gen Microbiol 128:1415-1422

Boschker HTS, Nold SC, Wellsbury P, Bos D, de Graaf W, Pel R, Parkes RJ, Cappenberg TE (1998) Direct linking of microbial populations to specific biogeochemical processes by $\mathrm{C}^{13}$-labelling of biomarkers. Nature 392:801-805

Boschker HTS, de Graaf W, Koster M, Meyer-Reil LA, Cappenberg TE (2001) Bacterial populations and processes involved in acetate and propionate consumption in anoxic brackish sediment. FEMS Microbiol Ecol 35:97-103

Boudreau BP, Westrich JT (1984) The dependence of bacterial sulfate reduction on sulfate concentration in marine sediments. Geochim Cosmochim Acta 48:2503-2516

Devereux R, Kane MD, Winfrey J, Stahl DA (1992) Genusand group-specific hybridisation probes for determinative and environmental studies of sulfate-reducing bacteria. Syst Appl Microbiol 15:601-609

Devereux R, Winfrey MR, Winfrey J, Stahl DA (1996) Depth profile of sulfate-reducing bacterial ribosomal RNA and mercury methylation in an estuarine sediment. FEMS Microbiol Ecol 20:23-31

Hussey A, Long SP (1982) Seasonal changes in weight of above- and below-ground vegetation and dead plant material in a salt marsh at Colne Point, Essex. J Ecol 70: $757-772$

Jørgensen BB (1982) Mineralisation of organic matter in the sea-bed-the role of sulfate reduction. Nature 296: 643-645

Kristjansson JK, Schönheit P, Thauer RK (1982) Different $K_{s}$ values for hydrogen of methanogenic bacteria and sulfatereducing bacteria: an explanation for the apparent inhibition of methanogenesis by sulfate. Arch Microbiol 131: 278-282

Krylova NI, Janssen PH, Conrad R (1997) Turnover of propionate in methanogenic paddy soil. FEMS Microbiol Ecol 23:107-117

Laanbroek HJ, Pfennig N (1981) Oxidation of short-chain fatty acids by sulfate-reducing bacteria in freshwater and marine sediments. Arch Microbiol 128:330-335

Li JH, Purdy KJ, Takii S, Hayashi H (1999) Seasonal changes in ribosomal RNA of sulfate-reducing bacteria and sulfate reducing activity in a freshwater lake sediment. FEMS Microbiol Ecol 28:31-39

Long SP, Mason CF (1983) Saltmarsh ecology. Blackie, London

Lovley DR, Klug MJ (1983) Sulfate reducers can outcompete methanogens at freshwater sulfate concentrations. Appl Environ Microbiol 45:187-192

Lovley DR, Dwyer DF, Klug MJ (1982) Kinetic analysis of competition between sulfate reducers and methanogens for hydrogen in sediments. Appl Environ Microbiol 43: 1373-1379

Minz D, Fishbain S, Green SJ, Muyzer G, Cohen Y, Rittmann BE, Stahl DA (1999) Unexpected population distribution in a microbial mat community: sulfate-reducing bacteria localized to the highly oxic chemocline in contrast to a eukaryotic preference for anoxia. Appl Environ Microbiol 65:4659-4665

Munson MA, Nedwell DB, Embley TM (1997) Phylogenetic diversity of Archaea in sediment samples from a coastal salt marsh. Appl Environ Microbiol 63:4729-4733

Nedwell DB, Banat IM (1981) Hydrogen as an electron donor for sulphate-reducing bacteria in slurries of salt marsh sediment. Microb Ecol 7:305-313

Nedwell DB, Gray TRG (1987) Soils and sediments as matrices for microbial growth. In: Fletcher M, Gray TRG, Jones JG (eds) Ecology of microbial communities. Society for General Microbiology 41st Symposium. Cambridge University Press, Cambridge, p 21-54

Nedwell DB, Takii S (1988) Bacterial sulphate reduction in sediments of a European salt marsh: acid-volatile and tinreducible products. Estuar Coast Shelf Sci 26:599-606

Nedwell DB, Watson A (1995) $\mathrm{CH}_{4}$ production, oxidation and emission in a UK ombrotrophic peat bog-influence of $\mathrm{SO}_{4}{ }^{2-}$ from acid-rain. Soil Biol Biochem 27:893-903

Nedwell DB, Blackburn TH, Wiebe WJ (1994) Dynamic nature of the turnover of organic carbon, nitrogen and sulphur in the sediments of a Jamaican mangrove forest. Mar Ecol Prog Ser 110:223-231

Ogilvie B, Nedwell DB, Harrison RM, Robinson A, Sage A (1997) High nitrate muddy estuaries as nitrogen sinks: the nitrogen budget of the River Colne estuary (United Kingdom). Mar Ecol Prog Ser 150:217-226 
Parkes RJ, Gibson GR, Mueller-Harvey I, Buckingham WJ, Herbert KA (1989) Determination of the substrates for sulfate-reducing bacteria within marine-estuarine sediments with different rates of sulfate reduction. J Gen Microbiol 135:175-187

Purdy KJ (1997) The use of 16S rRNA-targeted oligonucleotide probes to study the ecology of sulphate-reducing bacteria. PhD thesis, University of Essex, Colchester

Purdy KJ, Embley TM, Takii S, Nedwell DB (1996) Rapid extraction of DNA and rRNA from sediments using a novel hydroxyapatite spin-column method. Appl Environ Microbiol 62:3905-3907

Purdy KJ, Nedwell DB, Embley TM, Takii S (1997) Use of 16S rRNA-targeted oligonucleotide probes to investigate the occurrence and selection of sulphate-reducing bacteria in response to nutrient addition to sediment slurry microcosms from a Japanese estuary. FEMS Microbiol Ecol 24: 221-234

Purdy KJ, Nedwell DB, Embley TM, Takii S (2001) Using 16S rRNA-targeted oligonucleotide probes to investigate the distribution of sulphate-reducing bacteria in a Japanese estuary. FEMS Microbiol Ecol 36:165-168

Purdy KJ, Embley TM, Nedwell DB (2002) The distribution and activity of sulphate reducing bacteria in estuarine and coastal marine sediments. Antonie Leeuwenhoek 81: 181-187

Purdy KJ, Munson MA, Embley TM, Nedwell DB (2003a) Use of 16S rRNA-targeted oligonucleotide probes to investigate function and phylogeny of sulphate-reducing bacteria and methanogenic archaea in a UK estuary. FEMS Microbiol Ecol 44:361-371

Purdy KJ, Nedwell DB, Embley TM (2003b) Analysis of the sulphate-reducing bacterial and methanogenic archaeal populations in contrasting Antarctic sediments. Appl Environ Microbiol 69:3181-3191

Rosset R, Julien J, Monier R (1966) Ribonucleic acid composition of bacteria as a function of growth rate. J Mol Biol 18: 308-320

Sahm K, Knoblauch C, Amann R (1999a) Phylogenetic affiliation and quantification of psychrophilic sulfate-reducing isolates in marine Arctic sediments. Appl Environ Microbiol 65:3976-3981

Sahm K, MacGregor BJ, Jørgensen BB, Stahl DA (1999b) Sulphate reduction and vertical distribution of sulphate-reducing bacteria quantified by rRNA slot-blot hybridization in a coastal marine sediment. Environ Microbiol 1:65-74

Editorial responsibility: Frede Thingstad,

Bergen, Norway
Sambrook J, Fritsch EF, Maniatis T (1989) Molecular cloning: a laboratory manual. Cold Springs Harbor Laboratory Press, Cold Springs Harbor, NY

Scholten JCM, van Bodegom PM, Vogelaar J, van Ittersum A, Hordijk K, Roelofsen W, Stams AJM (2002) Effect of sulfate and nitrate on acetate conversion by anaerobic microorganisms in a freshwater sediment. FEMS Microbiol Ecol 42:375-385

Schutz H, Schröder P, Rennenberg H (1991) Role of plants in regulating the methane flux to the atmosphere. In: Sharkey TD, Holland EA, Mooney HA (eds) Trace gas emissions by plants. Academic Press, San Diego, CA, p 29-67

Senior E, Lindström B, Banat IM, Nedwell DB (1982) Sulfate reduction and methanogenesis in the sediment of a saltmarsh on the East coast of the United Kingdom. Appl Environ Microbiol 43:987-996

Skyring GW, Oshrain RL, Wiebe WJ (1979) Sulfate reduction rates in Georgia marshland soils. Geomicrobiol J 1:389-400

Szewzyk R, Pfennig N (1987) Complete oxidation of catechol by the strictly sulfate-reducing Desulfobacterium catecholicum sp nov. Arch Microbiol 147:163-168

Takii S, Fukui M (1991) Relative importance of methanogenesis, sulfate reduction and denitrification in sediments of the lower Tama river. Bull Jpn Soc Microb Ecol 6:1-8

Trimmer M, Nedwell DB, Purdy KJ (1997) Process measurement and phylogenetic analysis of the sulphate reducing bacterial communities of two contrasting benthic sites in the upper estuary of the Great Ouse, Norfolk, UK. FEMS Microbiol Ecol 24:333-342

Watson A, Stephen KD, Nedwell DB, Arah JRM (1997) Oxidation of methane in peat: kinetics of $\mathrm{CH}_{4}$ and $\mathrm{O}_{2}$ removal and the role of plant roots. Soil Biol Biochem 29:1257-1267

Widdel F, Bak F (1992) Gram negative mesophilic sulfatereducing bacteria. In: Balows A, Trüper HG, Dworkin M, Harder W, Schleifer KH (eds) The procaryotes: a handbook on the biology of bacteria: ecophysiology, identification, application. Springer Verlag, New York, p 3352-3378

Winfrey MR, Ward DM (1983) Substrates for sulfate reduction and methane production in intertidal sediments. Appl Environ Microbiol 45:193-199

Winfrey MR, Zeikus JG (1977) Effect of sulfate on carbon and electron flow during microbial methanogenesis in freshwater sediments. Appl Environ Microbiol 33:275-281

Zar JH (1996) Biostatistical analysis. Prentice-Hall International (UK), London

Submitted: May 5, 2004; Accepted: October 18, 2004

Proofs received from author(s): November 19, 2004 